\title{
EMPIRICAL RESEARCH ON OFFERS OF SETTLEMENT: A PRELIMINARY REPORT
}

\author{
Thomas D. Rowe, JR., * with NeIL Vidmar $\dagger$
}

\section{INTRODUCTION}

This paper reports on results from the early stages of an ongoing empirical study of the "offer of settlement" or "offer of judgment" device. Emphasis on and controversy over encouraging settlement in civil litigation, along with interpretations and proposed (but withdrawn) amendments of Federal Rule of Civil Procedure 68 on offers of judgment, have underscored the potential of this procedural tool. We have little systematic knowledge, however, about what effects the offer of settlement device might actually have in the different contexts in which it could be used and in the different forms in which it could be cast. The present study attempts to begin filling that gap with reports on simulation research. In the future, we hope to continue our efforts with experimentation on actual disputes.

Our report begins with a description of the background against which the study takes place-the existing rules and current issues concerning possible changes. It describes the promise and dangers of offer devices and the potential significance of empirical research in this field. It then turns in Part II to a description of our study-its design and the hypotheses to be tested. We report in Part III on findings from simulations using Duke University law and business students and Washington University law students. The report concludes in Part IV with discussion of the policy implications of our findings if they were to be borne out by more extensive research, and with mention of possible later and more complex stages in the research and more advanced hypotheses that might also be tested in these phases.

\section{A. Setting}

1. Rule 68 and the American Rule on Attorney Fee Liability. Federal Rule of Civil Procedure 68, along with many parallel state rules, provides that if a

\footnotetext{
Copyright (c) 1988 by Law and Contemporary Problems

* Professor of Law, Duke University. I gratefully acknowledge support for work on this study from the National Institute for Dispute Resolution and the Eugene 1. Bost Research l'rofessorship funded by the Charles A. Cannon Charitable Trust No. Three. The opinions and conclusions expressed in the article do not necessarily reflect the views of the granting institutions.

$\dagger$ Professor of Social Science and Law, Duke University School of Law; Vice President for Research, Private Adjudication Center.
} 
defendant offers to have judgment entered against him, the plaintiff does not accept, and the plaintiff's judgment is not more favorable than the offer, then the plaintiff must pay the defendant's post-offer costs. ' The effect is to reverse the usual rule that a losing party must pay the winner's costs; the baseline for judging who "won" for purposes of entitlement to costs rises from zero to the amount of the defendant's offer. The mandatory phrasing of the rule also eliminates the court's normal discretion not to award costs to a prevailing party." "Costs" in this country, however, are often little more than nominal, and in particular under the decisional "American rule" do not usually include attorneys' fees. 3 Thus, the normal impact of a Rule 68 offer, and consequently the rate at which defendants have used the Rule, have not been great. ${ }^{+}$Several developments, however, have combined in recent years to raise the visibility of the device.

\section{The Controversy over Encouraging Settlement. Concern over rising caseloads} has led to increased focus on and encouragement of settlement. Greater judicial fostering of settlement has been one of the hallmarks of "managerial" judges' procedural activism," and the 1983 amendments to Federal Rule of Civil Procedure 16 on pretrial conferences gave legitimacy to such judicial efforts by adding two mentions of settlement to the text of the Rule." The

1. Federal Rule of Civil Procedure 68 reads in full:

At any time more than 10 davs before the trial begins, a party defending against a claim may serve upon the adverse party an offer to allow judgment to be taken against the defending party for the money or property or to the effect specified in the offer, with costs then accrued. If within 10 days after the service of the offer the adverse party serves written notice that the offer is accepted, either party may then file the offer and notice of acceptance logether with proof of service thereof and thereupon the clerk shall enter judgment. An offer not accepted shall be deemed withdrawn and evidence thereof is not admissible except in a proceding to determine costs. If the judgment finally obtained by the offeree is not more favorable than the offer, the offeree must pay the costs incurred after the making of the offer. The fact that an offer is made but not accepted does not preclude a subsequent offer. When the liability of one pary to another has been determined by verdict or order or judgment, but the amount or extent of the liability remains to be determined by further procecdings, the party adjudged liable may make an offer of judgment, which shall have the same effect as an offer made before trial if it is served within a reasonable time not less than 10 days prior to the commencement of hearings to determine the amount of extent of liabilit:

FED. R. Cir. P. 68.

2. On the application of Rule 68 , see generally, e.g. Note, Rule 68: 4 ". Tere" Tool for Litigation, 1978 Duke I.J. $889,889-93$.

3. On cosis in general, sec $10 \mathrm{C}$. Wright, A. Miller \& M. Kane, Federat. Practich and Procedire $\$ \$ 2665-79$ (2d ed. 1983); on the American rule against fec shifting generally and exceptions under federal law, see $i d$. $\$ 2675$.

4. Sep. P.g., Committec Note, Preliminary Draft of Proposed Amendments to the Federal Rules of Ciril Procedure, 98 F.R.D. 339,363 (1983) |hercinalier 1983 Prelimimany Draft].

5. See generally, e.g., Sumposium, Litigation Mamagement. 53 U. CH1. L. Rev. 305 (1986).

6. Fe.1). R. Civ. P. IG(a) ("In any action, the court may in it discretion direct the attorneys for the parties and any unrepresented parties to appear before it for a conference or conferences before trial for such purposes as . . (5) facilitating the settement of the case."); FE1). R. C.Iv. P. 16(c) ("Ihe participants at any conference under this rule may consider and take action with respect to... (7) the possibility of setlement or the use of extrajudicial procedures to resolve the dispute ... ."); see Fiso. R. Civ. P'. Advisory Committec's note to 1983 amendments:

Clause (7) explicitly recognizes that it has become commonplace to discuss seulement at pretrial conferences. Since it obviously eases crowded court dockets and results in savings 
idea of encouraging settlement has been both enthusiastically embraced as a necessary response to court congestion and litigant intransigence, and strongly criticized for running risks of compromising judicial neutrality, forcing abandonment of legal rights, and reducing judicial articulation of important public values. ${ }^{7}$ More effective forms of the offer of settlement rule, which works without judicial involvement (at least until after judgment), could be an attractive way to gain the benefits of promoting settlement without some of the costs-if forms of the rule can be devised that do not entail too many problems of their own.

3. Proposed Amendments to Federal Rule 68. In 1983 and 1984, the federal Advisory Committee on Civil Rules proposed amendments to Rule 68. Many of the details of the proposals are not relevant here, but both versions involved key changes that are the basis for our first simulation. With the aim of improving both the fairness and the effectiveness of the Rule, the revisions would have (1) made the offer device available to plaintiffs as well as defendants, and (2) added attorneys' fees to the costs for which a party declining an offer of settlement under the Rule could be liable. The proposals aroused a good deal of criticism," and the Committee has apparently shelved the topic, at least for the time being. ${ }^{10}$ Part of the reason for the opposition was concern about the possible impacts of the proposed changes; the concern may be well founded, but at present it rests on theoretical analysis and informed practical speculation rather than empirical research. In some cases even the direction of likely effects from changes in the Rule is uncertain; and even when little reason exists to doubt the direction, the magnitude of the impacts may be unknown. This magnitude could be significant for policy decisions about the desirability of amendments. Our first simulation therefore uses variations on the Advisory Committee's proposed changes with two-way and fee-affecting characteristics.

\footnotetext{
to the litigants and the judicial system, settement should be facilitated at as early a stage of the litigation as possible. Although it is not the purpose of Rule $l(6(b)(7) \mid$ sic $\mid$ to impose sculement negotiations on unwilling litigants, it is believed that providing a neutral forum for discussing the subject might fosice it.
}

7. For the leading criticism of setulement, see Fiss, fyamst Settement, 93 Yat. I.J. 1073 (1984). For a response and Fiss reply, see McThenia \& Shaffer, For Reconrilatim, 94 Yat. L.J. 1660 (1985); Fiss, Out of Edem. 94 Yat. I.J. 1609 (1985). See also Macklin. Promoting Setllement. Foregoing the Facts, 14 N.Y.U. Rev. I. \& Soc. Chance: 575 (1986) (stressing social values of judicial factfinding and questioning whether alternative dispute resolution and promoting settement excessively reduce factfinding). For a survey of attitudes about judicial roles and techniques in connection with

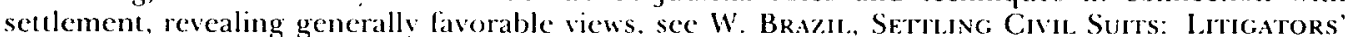
Vifws Abolt Appropriate Rol.s and Effective Teciniques for Federal. Judges (1985).

8. 1983 Preliminary Draft. supra note 4, 98 F.R.D. at $361-67$; Preliminary Draft of Proposed Amendments. 102 F.R.D. $407.432-37$ (1984).

9. See. e.g. Burbank. Proposals to fmend Rule 68 -Time to Abomdon Ship, 19 U. Micn. J.L. REF. 425 (1986); Simon, The Riddle of Rule 68, 54 Geo. Wasn. 1. Rev. 1. 10-19 (1985). Among the objections most vigorously urged were that the proposals were too severe in their likely effects on plaintifls; that they ran counter to congressional policy in federal fee shifing laws; and that they exceeded the rulemakers" authority under the Rules Enabling Act, 28 U.S.C. \$2072 (1982).

10. Sep Simon, supra note 9, at 24 n.142. 
4. Recent Decisions. Another development that occurred in the 1980's to increase the prominence of the offer device was the decision of two Supreme Court cases involving Federal Rule 68. The first, Delta Air Lines v. August, ${ }^{11}$ turned on a fairly fine point of interpretation, holding that a complete victory for a defendant does not trigger the Rule's mandatory costs award because such a case does not come within the Rule's language requiring a "judgment ... obtained by the offeree" (plaintiff). As a result, the courts retain their usual discretion in deciding whether to award costs. Both the majority and dissenting opinions, however, did emphasize the Rule's goal of promoting settlement. ${ }^{12}$

The Court's more significant decision four years later in Marek v. Chesny ${ }^{13}$ has drawn considerable attention ${ }^{14}$ and affords the basis for one of the simulations reported on later in this article. The Civil Rights Attorney's Fees Awards Act of 1976 ("section 1988")15 provides for the award of attorney fees to a prevailing party in federal civil rights actions "as part of the costs." Marek held that the reference to "costs" in Rule 68 includes attorney fees awardable under section 1988; consequently, a federal civil rights plaintiff who declines and fails to improve on a defendant's Rule 68 offer loses the usual entitlement to recover post-offer fees. Marek failed to present the issue whether a plaintiff's entitlement is not merely neutralized, but reversed, with such a plaintiff becoming liable for the defendant's post-offer fees. The leading lower court case on that point since Marek, Crossman v. Marcoccio, held that "Rule 68 can never require prevailing civil rights plaintiffs to pay defendants' post-offer attorneys' fees."16 Without taking any position on the legal or policy desirability of the various approaches, our second simulation tests for different effects of the three main possible rules: leaving the plaintiff's section 1988 fee entitlement unaffected by an unbeaten Rule 68 offer; neutralizing the entitlement; and reversing it.

5. Commentary About Offer Devices. Among the sources available to those discussing the proposed Rule 68 amendments and the Supreme Court rulings was a considerable literature in legal and economic publications, some of it commentary on the amendments or the decisions themselves. ${ }^{17}$ Other works of a more theoretical nature have attempted to use economic analysis to

11. 450 U.S. $346(1981)$.

12. Id. at 352 (Stevens, J.); id. at 380 (Rehnquist, J., dissenting).

13. 473 U.S. 1 (1985).

14. See, e.g., Simon, The Vea Merming of Rule 68: Marek v. Chesny and Beyond, 14 N.Y.U. REN. 1. \& Soc. Change 475 (1986).

15. 42 U.S.C. $\$ 1988(1982)$

16. 806 F.2d 329, 334 (1 st Cir. 1986), cert. denied. 107 S. C1. 1955 (1987). Sef also Hopper v. Euclid Manor Nursing Home, Inc., 867 F.2d 291,296 (6th Cir. 1989) (when trial court declined io award attorney fees to defendant under section 1988 , fees "never became a part of the costs 10 be awarded under Rule 68").

17. Sep, e.g., Burbank, supra note 9; Oesterle, Proposed Rule 68 on Offers of Settlement. Corneit. L..F.. Feb. 1984, at 11; Simon. supra note 9; Simon, supra note 14; Note, supra note 2; Toran, Sellement. Sanctions, and Allomey Fres: Comparing English Payment into Count and Proposed Rule 68, 35 Am. U.1.. REv. 301 (1986); Note, Offer of Judgment and Statutorily Authorized Altomey is Feps: A Reconciliation of the Srope and Purpose of Rule 68, 16 GA. I. Rev. 482 (1982). 
predict the likely effects of offer rules entailing greater consequences than existing Rule 68. is These writings have raised issues and developed hypotheses that our empirical research attempts to explore and test.

\section{B. Potential Benefits and Problems of Offer Devices}

Offer devices are especially interesting, and empirical research on them is potentially quite significant, because the devices present such a complex mixture of possible benefits and dangers. That combination poses challenges both for research and for the rulemaker's craft, and we hope in later stages of our research to test rule forms drafted in light of the results of our present study. To avoid getting ahead of the story, however, we summarize here the basic types of foresecable benefits and problems.

1. Possible Benefits. Formal offer of settlement rules affecting liability for post-offer attorneys' fees may have significant "smoke-out" effects, eliciting realistic settlement offers early by giving parties a potential gain (fee recovery or avoiding fee liability) from making such offers to offset any possibility of appearing weak in negotiations. ${ }^{19}$ Similarly, they give the other side an incentive, the threat of fee liability or losing fee entitlement, to take such offers seriously rather than simply holding out for something better. The result, even if the effect is not to make parties more likely to settle, could well be that cases that were going to settle anyway settle sooner-with faster relief for those suffering legal injury and transaction cost savings for litigants and the system. $: 0$

Second, offer devices affecting liability for post-offer fees should give parties with strong claims or defenses, who otherwise might have to yield more in negotiations than the merits seem to warrant (because of the threat of unrecoverable fees), an effective way of countering groundless opposition." Offer devices may thus discourage both efforts to force "discounting" of strong claims and attempts to stand on nuisance claims for their settlement value. Third, offer rules may help fulfill a goal of remedial law, full compensation of injured plaintiffs. Rather than being limited to damages minus a large attorney's fee, a party with a strong claim who makes a reasonable, early offer seems likely to get an early settlement with relatively little fee expense or a judgment including a fee award. Similarly, a defendant

18. See, e.g., J. Shapard, Ihe Infliknce of Rulfes Respecting Recovery of Atrorneys Fegs on Setrlement of Civil. Cases (1984): Bowles, Economic Aspects of Legal Procedure, in The Economic Approach to Law 191, 197-201 (1981): Cooter, Marks \& Mnookin, Bargaining in the Shadow of the Law:

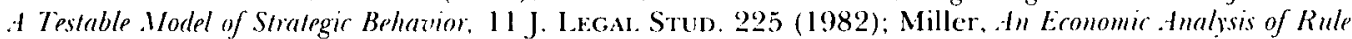
68. 15 J. Legal. STud. 93 (1986); Oesterle, supra note 17; Phillips \& Hawkins, Some Eronomic Asperts of the Settlement Process: A Study of Personal Injury Claims. 39) Mod. L. REv. 497 (1976); Pricst. Regulating the Conlem and lolume of litigation: In Economic Inalysis, I Sup. Cr. Econ. Rrv. 163 (1982); Rowe, Predicting the Efferts of Attormey Fe Shifting, 47 Law \& Contemp. Probs., Winter 1984, at 139. Rather than attempt to summarize the points in these several works here, we cite specific portions when they are relevant to particular hypotheses.

19. Spe. e.g. Cooter, Marks \& Mnookin. supra note 18. at 244-45.

20. Spe, e.g., Kowe, supra note 18, at 166-69.

21. Sep id. at 169. 
could be compensated for expenses suffered because of a plaintiff's unjustified persistence.

2. Dangers and Problems. Offer devices also pose problems that no responsible discussion can overlook. First, the positive "smoke-out" phenomenon that may accelerate settlement seems inseparable from a potential "dig-in" effect, which will sometimes make agreement less likely if the parties do not settle after making formal offers. The very reason why it is attractive to make an offer is that it improves the offeror's expected outcome from trial-fee recovery if the adversary rejects the offer and does not improve on it. With the expected outcome from trial improved, of course, trial itself is less to be feared if the other side does not accept the offer; the formal offer provision thus may harden positions."2

Second, fee-affecting offers may be a powerful weapon against the riskaverse, because they can introduce the possibility of substantial loss or at least large reduction in recovery where none existed before. A large employer defending against a discrimination claim or an insurance company representing the defendant in an ordinary tort case, for example, might "lowball" a claimant with an ungenerous offer. Then even the fairly small chance that a verdict will come in below the offer, and be largely eaten up by the fees of the defense counsel (or worse, be exceeded by defense fees, leaving the plaintiff with a net loss), might drive an underfinanced claimant to accept much less than the likely fruits of trial.2:3

Third, offer rules may undercut the goals of congressional fee award statutes by reducing the encouragement Congress meant to give plaintiffs. $2-4$ A holding that under Marek civil rights plaintiffs not only lose their entitlement to post-offer fees if they fail to improve on a rejected offer, but also become liable for defendants' fees, would probably disadvantage a strongly risk-averse group-individuals with discrimination claims. It could thus inhibit significantly the pursuit of civil rights claims, a questionable effect for a procedural rule in light of Congress' substantive concerns underlying both the civil rights acts and section 1988.25

This background-the setting and the pros and cons of offer devicesunderscores the potential significance of empirical data on the workings and impact of offer rules. Of course, normative factors will and should play a

22. See Priest, supra note 18, at 169-71: Rowe, supra note 18 , at $166-68$

23. Sep Rowe, supro note 18. at 168-69. The uncertainty that plays on risk aversion derives partly from the fact that verdicts in the same case from different triers will vary over a range of probable outcomes. To reduce both strong impacts due to risk aversion and unfairness duc 10 random fluctuations, offer rules could provide for fec liability only if the ofleree not only failed to improve on the offer but the judgment did not come within a certain range of it. A plaintifl rejecting a defendant's offer of $\$ 20.000$, for example, might have to improve not on the offer but on, say, the offer minus $25 \%$ or $\$ 15,000$. Similarly, a defendant rejecting a demand of $\$ 15,000$ might need only a judgment under $\$ 20,000$, the offer plus one-third, to avoid fee liability. For simplicity. our simulations included no such cushions, but we do not mean to prejudge these drafing issues.

24. Simon, supra note 9. at 14-15.

25. Rowe, The Supreme Court on Altomey Fee Auturds, 1985 and 1986 Terms: Economics, Ethics, and Ex

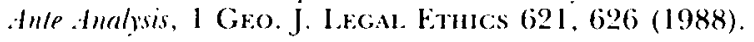


major role in policy decisions whether to adopt or modify such provisions; but far too often we know next to nothing about how great or little a difference such changes would make. More broadly, scholars have noted for decades the dearth of empirical work on the effects of attorney fee shifting, ${ }^{26}$ and results bearing on such questions as the strength of risk aversion among parties of certain types could have import for litigation finance issues beyond the field of offer devices. ${ }^{27}$

\section{II}

\section{Design and Goals of the Study}

\section{A. Research Design}

For this first phase of the project, we ran two fairly simple simulations on student populations. The subjects received hypothetical factual situations and basic explanations of the workings of the types of offer rules involved. ${ }^{28}$ Each student received a series of three variations under the same basic fact pattern, with a different rule type and offer level under each scenario. The subjects were asked in each case whether they would accept the other side's offer and, if not, whether they would at that point make a counter-demand and if so for how much. The student populations used consisted of law and graduate business students at Duke University and law students at Washington University in St. Louis." The grant for the research from the National Institute for Dispute Resolution made it possible to pay respondents $\$ 10$ or $\$ 15$ for a completed questionnaire; most students were not required to take part but given the chance to do so for a modest payment, which eliminated

26. See. P.g. McCormick. Counsel Feps and Other Expenses of Litigation as an Element of Damages, 15 Minn. I. Rex. 619, 642 (1931); Sands, Allomeys Feps as Rerouprable Costs, 63 A.B.A. J. 510.515 (1977). For a recent exception reporting on a study of filings in three federal districts and reaching the somewhat surprising conclusion that the avalability of fee awards under section 1988 may have had litule effect on filing rates for constitutional wit cases, see schwab \& Eisenberg. Explaiming Constitutional Tont Litigation: The Influence of the Altormey Fees Statule and the Gotermment as Defendant, 73 Coknfil. L. Rriv. 719 (1988).

27. Sep, p.g., Rowe, supra note 18. a $158-59$ (discussing effect of risk aversion on likelihood of settement under fee shifting).

28. This experimcutal design may lead to results that exaggerate the effects of offer rules because the design requires that the subjects receive an explamation of the device-which emphasizes it and may focus their thinking on it more than would be the case in actual litigation with all its complexities. In reality, despite the possible gains from using the rule, parties may simply overlook it some amount of the time. Thus, this phase of our research may suffer from the problem of highlighting a key independent variable, with possible resulting increases in effects on the dependent variables. We hope in later work, with more complex simulations or experinents on actual disputes. to enhance realism by making the offer rules more a part of the general background, rather than underscoring them as seems unavoidable at this stage.

29. We are especially grateful to Professor Roy Simon of the law faculty at Washington University for his cooperation in administering the simulations to students there. We also appreciate comments and suggestions on the research design and earlier drafts of this report from members of an advisory group for the study: Stephen Burbank. Avery Katz. Iaura Macklin. Thomas Metzloft. Michael Meurer, Geofley Miller. Dale Oesterle, Judith Resnik, John Shapard, Roy Simon, and Janice loran. Any erross that remain are ours. 
any ethical issues of compulsion but may conceivably have introduced some self-selection bias of uncertain direction in the samples. ${ }^{30}$

To explain the design in slightly more detail: After the common introductory material and hypothetical fact pattern, each research instrument contained three different combinations of offer amounts and rule types to which students were asked to respond. Offer amounts were at three specific levels, which can be generically labeled low, medium, and high. Similarly, rule types were of three kinds, involving minimum, intermediate, and maximum consequences. Hence there were nine possible scenarios, of which each subject received three; the combinations and orders were systematically scrambled in an effort to minimize priority effects. "31 Thus, if the low, medium, and high offer amounts are abbreviated as 1, 2, and 3, and the minimum-, intermediate-, and maximum-consequence rule types as $\mathrm{A}, \mathrm{B}$, and $\mathrm{C}$, one subject would receive scenarios A 1, B2, and C3; another would receive $B 1, C 2$, and $A 3$; a third would receive $\mathrm{C} 1, \mathrm{~A} 2$, and $\mathrm{B} 3$; and so on. Running all combinations, as we did, without duplicating rule type or offer level for the same respondent yields thirty-six different forms of the survey instrument.32

The first simulation involved an ordinary personal injury tort claim in which students (some law, some business) were asked to imagine themselves in the role of the plaintiff. Liability was not an issue, but damages were contested. The amounts being offered by the defense in the various scenarios under this simulation were $\$ 30,000, \$ 35,000$, and $\$ 40,000$. The minimumconsequence offer rule was no formal provision at all-which leaves intact the American rule, with no prospect of fee recovery either way. (For simplicity, in all questionnaires non-fee "costs" were stipulated to be negligible.) The maximum-consequence version provided for full liability for the defense's reasonable post-offer attorney fees if the plaintiff declined and failed to improve on the defendant's offer. Under this rule the plaintiff could also make a counter-demand with the same effects in reverse. The third, intermediate-consequence version was based on a proposal by John Shapard of the Federal Judicial Center for a "benefit-of-the-bargain" approach;33 in brief, a party whose rejected offer was not bettered at trial would be entitled to some benefit but not full recovery of all reasonable post-offer fees. Such a

30. The exception was the group of Duke graduate business students, all of whom completed the questionnaire without payment as part of a class exercise. For their assistance in arranging the administration of the simulation to this group. we are grateful to Professor Blair Sheppard and Jonclle Roth of the Fuqua School of Business.

31. This design makes it possible to check for these priority effects-whether respondents' answers vary in any systematic ways with the order in which they encountered scenarios in their questionnaires. We have run some statistical tests for such effects and found none that are significant. Suggestions of possible patterns do appear from the raw figures, such as a slighty higher acceptance rate in the last scenario in a questiomaire: but in addition to not being statistically significant at the 05 level in aggregate data, this tendency is not uniform anong the subject populations taken scparately. (For a brief explanation of statistical significance, sec infra note 43.) In this report, therefore, all data are aggregale within sample populations. making no differentiation for response order.

32. Sample forms of the survey instruments are available from lrofessor Rowe, who will be glad to help anvone interested in replicating existing or future simulations.

33. Ser J. SHatarl), supra notc 18, al 53-55. 
party could elect the more advantageous of the trial verdict or (in the case of a defendant) the offer minus reasonable post-offer fees. ${ }^{34}$

In the second simulation, the hypothetical situation involved a civil rights suit against police for several claims arising out of a mistaken-address drug bust; subjects (all law students) were asked to play the role of plaintiffs' counsel. ${ }^{35}$ The basic questions asked, however, remained similar: Would you advise acceptance now; if not, would you advise a counter-demand, and in any event for how much? The offer levels were $\$ 6000, \$ 13,000$, and $\$ 20,000$. The rule types were the three main possible variations on the actual situation under section 1988 and present Federal Rule 68, which only defendants may invoke: leaving a federal civil rights plaintiff's fee entitlement unaffected; neutralizing it as in Marek $v$. Chesny; $;{ }^{3 i}$ and reversing the entitlement to provide for fee recovery by defendants. In both simulations the initial offer levels were meant to be realistic given the facts, and they indeed turned out to cover spans in which acceptance rates ranged from zero or quite low to fairly high or 100 percent.

\section{B. Hypotheses and Questions}

These simulations lend themselves to testing three main hypotheses about expected impacts of offer of settlement rules affecting liability for attorney fees, compared to regimes under which settlement offers and demands can have no such effect: (1) higher rates of acceptance of initial offers; (2) higher rates of plaintiffs making early counter-demands under a two-way offer rule, but not under a one-way rule, if the initial offers are not accepted; and (3) moderation of amounts in counter-demands. To elaborate somewhat on each of these, a plaintiff facing an offer that threatens to impose liability for postoffer defense fees should be more likely to accept that offer than he would be under a rule without such a consequence, because (if the offer is at all within the likely range of trial outcomes) it worsens the plaintiff's expected net from trial. To put it another way, the potential liability created by the formal offer rule should make the same offer relatively more attractive and thus more likely

34. For example. suppose a defendant makes a formal offer of $\$ 35.000$. plaintiff declines, and the verdict is $\$ 30,000$. If the defense's reasonable post-ofler fees are $\$ 10,000$, the defendant can choose to pay $\$ 25,000$ - the offer minus the fees; hence the "benefit-of-the-bargain" label, since the defendant was willing 10 part with $\$ 35,000$ and does so by paying $\$ 25,000$ and being $041 \$ 10,000$ in unreimbursed fees. At verdict levels below $\$ 25.000$ in this illustration, the defendant would choose to pay simply the verdict amount. This version has lesser consequences than the "plain vanilla" full liability rule, under which the plaintifl"s verdict would alwavs be reduced by the defendan's reasonable post-offer fees. This rule lype also includes a parallel benefit-of-the-bargain allowance for a rejected and unbeaten plaimiff s demand, with the plaintiff able to choose either the verdict on the one hand or, on the other, the demand amoun plus reasonable post-demand fees.

35. As in the first simulation, some liability was conceded for unlawful scarch, because of the address mistake): but damage amounts were at issue, as were major claims of false arrest and punitive damages because of a defense of excessive resistance. This article therefore does not deal with situations involving liquidated damages but contested liability, where offer rules could be expected not lo work well and exceptions of judicial discrerion might be needed. For discussion of this problem see Rowe, supra note 18 , al $166-67 \&$ n.119.

36. Sef supro lex1 accompanying notes $13-16$. 
to be accepted. 37 This hypothesis thus looks to the possibility that "low-ball" defense offers will have greater impact against plaintiffs under a formal offer rule. ${ }^{3 x}$

The second hypothesis-that of higher rates of making early counterdemands under a two-way rule if the offeree does not accept an initial offerinvolves the expected "smoke-out" effect."39 Without an offer rule and thus with no way of gaining a favorable fee shift by making a settlement demand, plaintiffs have less reason to make one. Some should be more likely to hold out without engaging in any back-and-forth, at least in the fairly early stages of litigation postulated in the simulations. Adding the possible benefit of fee recovery should lead to some increase in the tendency to make counterdemands early. The two different situations used in this study permit a comparative test of this hypothesis: In the first, one "rule" is no fee-affecting offer rule at all, while the other two rules provide for formal plaintiffs' counter-demands. The second situation involves one-way rules exclusively. Thus, in the first situation there should be a "smoke-out" effect under the two offer rules compared to the no-offer rule, while in the second there should be no resulting differential effect among rules, unless the expectation-lessening impact of a defendant's offer under the formal offer rules elicits more early counter-demands.

Third, the same incentive of possible gain from making a counter-demand should affect the amounts demanded. A plaintiff can plausibly expect to benefit from triggering fee liability in case of non-acceptance only if the formal demand is within the realistic range of likely outcomes. Without the chance of fee entitlement, however, some plaintiffs are likely to see less reason not to hang tough in initial exchanges, particularly for fear of appearing weak and setting too low a starting point for bargaining. This hypothesis thus relates to the expected effect of eliciting "reasonable" offers, ${ }^{40}$ which may be measured by the relative incidence of high outlying counter-demands and perhaps also by the mean amounts of counter-demands. The predicted result in the tort hypothetical is a lower rate of high outlying demands and a lower

37. This predicled effect is not the same as expecting an overall increase in the rate of settement. The simulations tested only for imitial acceptance; because they were not interactive and itcrative, they can yield no information about settlement likelihoods after initial rejection. Indeed. because of the possible "dig-in" eflect, sec supra text accompanying note 22, there is some reason to expect lower settement rates after initial rejections than if no fec-affecting offer rule applies. Interactive simulations or actual cases would be necessary to test for the "dig-in" effect and for net impacts on the overall rate of settement.

The prediction in the text would not hold in the case of a risk-neutral offeree who could make a counter-demand that might create liability for attomey fees. Unless the offer were attractive enough on its own, such a party should see and act upon the possibility of offscting a defendant's improvement in expected trial outcome by making a Rule fis counter-demand. But the simulation situations both involved supposedly risk-averse plaintifts, who should be driven toward acceptance by the wider uncertainty created by a defendant's offer; and the second situation (civil rights), based on the existing, one-way Federal Rule 68 , provides no way for a plaintiff to make a formal counterdemand affecting fee liability

38. Sep supra text accompanying note 23.

39. Sep supra text accompanying notes $19-20$

40. See supro text accompanying note 19 
mean amount demanded under the two rules providing for formal plaintiffs' counter-demands than under the no-offer rule. ${ }^{41}$

The simulation results may also make it possible to explore various questions about which it is often hard to formulate hypotheses in advance. Given the three-by-three matrix of increasing offer amounts and offer rules of lesser to greater consequences, we may be able to discern relative impacts of changes in the offer amounts and rules; one or the other might appear dominant, or the two might both seem to have considerable effect. The limited samples and number of offer levels used in our simulations so far, of course, preclude generalization at this stage; but if after more research rule effects were virtually always to appear relatively small, for example, the policy implication could be that the main ground for debate over such rules should be equity considerations rather than incentive effects. Similarly, it may be possible to compare the strength of impact of different rules, as with the intermediate benefit-of-the-bargain approach and the maximum-consequence full liability version in the first simulation. Finally, measurement of the gaps between initial offers and counter-demands could suggest some impact of initial offer levels on the amounts demanded-whether, for example, a fairly low offer seems to influence bargaining limits by eliciting low demands, or rather broadens them by making plaintiffs feel they must ask more to offset what looks like a hard bargaining position on the other side.

\section{RESULTS}

We ran our simulations on five student populations during the academic year 1987-88. Those receiving the tort situation were second-year Duke law students, second-year Washington University law students, and Duke graduate business students in a part-time program for those currently employed. The civil rights case was given to second-and third-year Duke law students (with no overlap between the first and second groups of Duke law student subjects) and Washington University law students, most of whom were late in their first year, along with a few second-years who had previously completed the tort situation questionnaire. The number of responses received from the various populations ranged from thirty-five to sixty-six, with response rates easy to reckon in some cases and harder in others. The Duke law students received the questionnaires in individual mail folders; 33 percent

41. A complicating factor, however, makes it difficult to be sure of the source of this result and to compare results under the tort and civil rights scenarios: Plaintiffs in our simulations, when considering how much to offer, were not making the initial bargaining move but were responding to defendants' offers-which, under the two offer rules, lowered the plaintiffs' expected net outcome from trial. Therefore, at least some demand moderation under offer rules in both the tort and civil rights simulations may have resulted from the effect of defendants' offers on plaintiffs expectations. lo test for offer or demand moderation due to the possible improved chances of fee recoverv alone. it would be necessary to study imital offers or demands rather than the counter-moves elicited in our simulations. We are indebted to John Shapard of the Federal Judicial Center for pointing out some of these implications of the eflect of defendants' initial offers on plaintiffs" expectations and likels demand levels. 
responded in one case and 27 percent in the second. The Washington University law students were invited to remain after class, and we do not have the numbers who chose to leave or not to complete the questionnaires. The Duke graduate business students filled out the questionnaire in class (and received no payment, unlike the others), so the response rate in that group was 100 percent.

\section{A. Tort Simulation}

The results from the tort simulations appear in Tables 1 through 4 in the Appendix. Tables 1, 2, and 3 present the results from the Duke University law, Washington University law, and Duke University graduate business students respectively; Table 4 aggregates the data from the three populations. The questionnaires contained minor variations because of our accumulating experience and the need to adapt to local differences, but the forms remained identical in their essential details. For the tort simulations, the offer amounts were $\$ 30,000, \$ 35,000$, and $\$ 40,000$; the rule types were none, benefit of the bargain, and full fee shifting. ${ }^{+2}$

Relating the results to the hypotheses, we find that in the aggregate data (Table 4) there is some increase in the overall rate of acceptance of initial offers as the offer rule goes from none (31.7 percent) to intermediate (benefit of the bargain-39.6 percent) to full (41.0 percent). It is not, however, statistically significant, with a chi-square probability of greater than .25 for the relationship between offer rule and acceptance rate. ${ }^{43}$ A different grouping of the data yields some higher suggestion of significance: If the subjects did not view the two offer rules as meaningfully different, but perceived that having some rule versus none could have a differential impact by creating the threat of any fee liability, it can make sense to group the two rule versions. When the "benefit" and full rules are combined, the difference between their 40.3 percent acceptance rate and that of 31.7 percent under no offer rule is marginally significant (less than .10).

The need to treat these results with caution becomes apparent when we examine the data for each subject group separately. All of the several probability figures for the relation between offer rule and acceptance rate-

42. See supra note 34 and text accompanying notes 33-34.

43. For those who are not used to dealing with statistical significance in legal writing, a brief and non-mathematical explanation may be in order. The "chi-square" procedure measures the likelihood that an observed pattern could be caused by random variation rather than by a true relationship between the factors. Chi-square probability figures run from 0 to 1 and, in the applications here, express the likelihood that a statistical relation between independent and dependent variables is due to chance. The higher the probability figure, the more likely the results are due to chance. By convention, figures of .05 or lower-one chance in twenty that the result is fortuitous-are widely accepted as reflecting statistical significance. Probabilities of .01 or lower, for which the phrase "significant at the .01 level" is sometimes used, are generally regarded as showing cren greater statistical significance. A figure of .10 may suggest that the relationship you think you are secing is the real thing, but you shouldn't take it to the bank.

The statistical programs used for this paper are mainfiame SAS version 5.18 and PC SAS version 6.03. For assistance in the statistical work we are gratcful to Bruce Burchett, a J.D. candidate at Duke, and for data tabulations to Julia Burchett of the Duke law class of 1985 . 
even combining the "benefit" and full rules-are above .15. Among the Washington University law students, as Table 2 reflects, the type of offer rule appears to have played no regular role in influencing acceptance rates, which were marginally lowest under the intermediate "benefit" rule (31.3 percent, compared with 32.8 percent under no offer and 40.6 percent with the full offer rule). Moreover, the acceptance rate under the full offer rule in this population was higher than under the other two rules at two of the offer levels $(\$ 30,000$ and $\$ 40,000)$ and lower at the third $(\$ 35,000)$, which strongly suggests random fluctuation given the fairly small numbers. ${ }^{44}$

Within the individual samples, the Duke University law students (Table 1) showed some tendency to accept offers at the lower two levels more under the offer rules than with no offer rule in force, which could suggest the effectiveness of "low-balling." The same impact appears in most but not all cases among the Duke business students (Table 3). Again, in this tort simulation with the Washington University law students (Table 2), however, no statistical significance showed up for any rule effects. Variations are evident within that group, but they are unsystematic enough to afford a textbook example of when statisticians would warn lay persons to draw no conclusions. ${ }^{45}$

44. The pattern in Table 2 could be consistent with the following explanation: With acceptance rates under the full offer rule markedly lowest at the medium $\$ 35.000$ offer, some respondents may have had a sense that the offer rule gives good leverage to try for a worthwhile small increase over the defendants offer. At the $\$ 40.000$ level, by contrast, there could be a stronger sense of doing rather well already, along with doubt about ability to get much more. One individual questionnaire strikingly illustrates this possibility: With no offer rule, the student accepted the low $\$ 30.000$ offer. citing the likelihood of having to wait a long time for trial. In the very next scenario, the same respondent rejected the $\$ 35.000$ offer under the full offer rule, speaking of the good chance of a verdict in the range of $\$ 40,000$ to $\$ 60,000$ (given in the facts) and also of recovering fees. Finally, under the intermediate "bencfit" rule, the student accepted the $\$ 40,000$ offer because there was "little chance of doing much better" and a risk of losing fees.

The contrast with another questionnaire in the same Washington University law student group, however, serves to caution against hasty generalization and to illustrate some sources of variation in the data. This student, who may not have understood the rule because he or she would have made no Rule 68 councer-offers despite their potential bencfits, would have arrepted only the $\$ 35.000$ offer. which happened to be under no ofler rule; the response cited the likely time to trial in case of rejection. Rejecting the $\$ 40,000$ offer under the "benefit" rule, the respondent cited the "great enough" chance of winning, which seems to reflect low risk aversion.

The emphasis in these iwo questionnaires on the danger of wating a long time for trial under no offer rule, leading the subjects to accept offers lower than others they rejected when some offer rule did apply, suggests that a somewhat paradoxical effect may occasionally arise with respect to timing of settement. In theory. Comal offer devices affecting liability for post-offer fees should often accelerate settements. Ser supra text accompanying note 20 . But sometimes, these two questionnaires suggest. the presence of the device may make it more attactive to try some bargaining, when otherwise the lack of bargaining leverage would have led to immediate acceptance. Of course, this effect may not dominate in the aggregate: there are two ways not to bargainacceptance or flat rejection-and the latter is likely to make the case take even longer. Moreover, it can serve justice if people do not have to accept what they regard as bad offers simply because otherwise they would suffer too much from delay. Still, focusing on the time factor, these questionnaires bring out how giving litigants an attracive new toy is likely in some instances to make them spend time playing with it. Because our simulations called for only a single set of responses and did not involve a bargaining process over lime, testing stech possibilities will have to await later research.

45. The lack of statistical significance in some of these data does not hold with respect to effects from the sheer amoum of the offer. Of course, it is to be expected that the higher the offer, the more 
The second hypothesis related to the "smoke-out" effect of eliciting early counter-demands. Subject to some caveats, there seems to be a degree of rule effect noticeable here. First, we are dealing with a reduced sample, since the relevant subgroups include only those respondents who said they would decline the defendant's initial offer. Second, large majorities within those subgroups make counter-demands under any rule; at least three-quarters in every scenario in every population said they would make a counter-demand once they rejected the initial offer. With the strong tendency to make counter-demands in any event, the observable differences in the counterdemand rate under the various rules are small.

Still, in two of the three groups and in the aggregate figures some distinctions do appear. Given the possible benefit of a favorable fee shift, under both versions of offer rules all of the Duke law students, and all but one of the Duke business students, who rejected the initial offers said they would make a counter-demand at this point. By contrast, at each of the three offer levels a small fraction of those samples under the no-formal-offer regime said they would not make any counter-demand. There was, however, no regularity on this matter among the Washington University law students. A comparison of the counter-demand rates under no offer rule and the combined rates under the "benefit" and full offer rules revealed that the rule influence was statistically significant in both Duke populations at least at the .05 level, but because of the small sample sizes involved these results must be interpreted with caution.

More importantly, aggregating all three populations (of which the Washington University group was the largest-sixty-six versus thirty-seven and thirty-eight in the Duke law and business groups respectively), the counter-offer rate was 85.3 percent under no offer rule and 92.2 percent under the "benefit" and full offer rules combined. Even with the large and non-confirming group included, the difference between these two percentages approached significance at better than the .10 level. Going out on a limb, we can say that there seems to be some marginal "smoke-out"

likely it will be accepted: if no such result appeared, one would question the rationality of the subject populations or the design of the survey instrument. In all three samples, although acceptance rates diverged fairly widely, there was indeed quite regular increase in aggregate acceptance rates as offer amounts rose; and despite the smallness of the samples. for the most part similar regular increases appeared even under each distinct rule type. In all of the tests we have run checking acceptance rate by offer amount, the statistical significance is high $(<.01)$. In this tort simulation, as opposed to the civil rights situation. offer amount appears to have been easily the single largest influence on acceptance rate. Indecd, in the Washington University law student group, offer amount seemed to be virtually or totally dominant in determining acceptance rate.

Professor Roy Simon of Washington University School of Law, who administered the questionnaire to student groups there, and Professor Rowe have discussed the lack of relationship between offer rule and acceptance rate in the responses of the Washington University law student group that answered the tort questionnaire. Especially since the group behaved rationally in other respects (higher acceptance rates with higher offers) and showed some rule effects (significantly lower counter-demand amounts under offer rules), and since the other Washington University law student group that answered the civil rights questionnaire showed significantly increasing acceptance rates as offer rule consequences became greater, we are at a loss to explain the lack of effect for offer rule on acceptance ratc in the first Washington University student sample. 
effect on early offers from the existence of an offer rule that creates a possibility of fee recovery.

The final hypothesis concerns the amounts counter-demanded and whether they would be somewhat moderated by the availability of offer rules extending the possible benefit of a favorable fee shift. We have looked at both the mean counter-demand amount and the incidence of high outlying counter-demands-those of $\$ 60,000$ or higher (that figure representing the top of the range in which all students were told there was a good chance of a verdict). Both measures provide strong confirmation for this hypothesis, quite markedly when we take the three groups in the aggregate and to a considerable extent when the populations are treated separately. For the three groups together, the mean counter-demand under no offer rule was $\$ 56,345$, and $\$ 48,562$ under the two offer rules. The percentage of high outliers under no offer rule is 40.7 percent, but under the offer rules is only 9.8 percent. Both differences are significant at the .01 level.

Taking the three samples separately, in all possible instances the mean counter-demand under no offer rule was higher than that under the two offer rules combined; often the chi-square probability was at or near significant levels. Similarly, the percentage of high outlying counter-demands for all three groups was over 20 percent under no offer rule, and considerably lower under the offer rules. Significantly, in the Washington University sample, which had shown little if any response to the offer rules in its decisions whether to accept and whether to make a counter-demand, the effects of moderation of counter-demands were especially pronounced, with the largest decreases in any of the three groups both in average counter-demands and high outlying percentages. In sum, the expected incentive effect of some moderation on many subjects seems to be strongly confirmed. Of course, by no means do all subjects decide to start high under no offer rule, or refrain from high counter-demands under offer rules; but in our samples, having the offer rule available to plaintiffs does appear to have encouraged "reasonable" counter-demands.

\section{B. Civil Rights Simulation}

We present the results from the civil rights simulations in Tables 5 (Duke law students), 6 (Washington University law students), and 7 (totals) in the Appendix. With the exception of some variations in introductory materials because of local conditions, the questionnaires were identical. For this situation the offer levels were $\$ 6000, \$ 13,000$, and $\$ 20,000$. The rule types all involved the interaction of existing Rule 68 and civil rights attorney fee awards under section 1988. The first rule had no effect on a prevailing plaintiff's entitlement to post-offer fees (the position the Supreme Court rejected in Marek); the second neutralized that entitlement (the result in Marek and Marcoccio); and the third made the plaintiff liable for the defendant's 
reasonable post-offer fees in unbeaten-offer cases (the rule in no jurisdiction that we know of, but argued for unsuccessfully by the Marcoccio defendants). ${ }^{4(;}$

Especially striking about the results from this situation is the presence of marked rule effects on the likelihood of acceptance of the defendants' initial offer, in contrast with the tort hypothetical. In each sample and in the two samples combined, a comparison of all three rules separately and a comparison of the minimum-consequence rule with the two fee-affecting rules together reveal that the relationship between rule type and acceptance rate is always significant at the .01 level. This result, involving a simulation with rules having more clear-cut and perhaps more severe consequences, provides support for the first hypothesis that the threat of an adverse fee shift should increase the acceptance rate. Unsurprisingly, the offer amount still correlates strongly with acceptance; but here the rule effect is also pronounced and quite regular. In an analysis of scenarios under the same offer amount with different rule types, the acceptance rate almost always rises with the progression from minimum- to intermediate- and maximum-consequence rules; the only variations are minor and appear insignificant.

Three effects apparent in these data with respect to acceptance rate seem especially noteworthy. First, there does appear to be a significant difference in effects between the intermediate- and maximum-consequence offer rules, which did not occur in the tort simulation. The distinction in consequencessimple inability to collect your own fees versus having to pay the other side's as well-is sharp and easy to grasp, perhaps unlike the more complex "benefit-of-the-bargain" rule as contrasted with the "plain vanilla" offer rule in the first situation.

Second, the effects on increasing acceptance are particularly strong with the combination of higher offer and stronger-consequence rule. Acceptance rates with the highest offer but minimum-consequence rule stayed below 42 percent; but in one sample with the medium offer and the maximumconsequence rule, and in both with the highest offer and intermediate- or maximum-consequence rule, the acceptance rate ran at least 58 percent and under one scenario in one sample was 100 percent. There may thus be a synergistic effect, strongest at upper levels, when the offer amount and the severity of the rule consequences rise together. Third, the data provide some indication that severe offer rules may enhance the acceptability of "low-ball" offers to risk-averse plaintiffs. No plaintiff in either sample would accept the $\$ 6000$ offer under the minimum- or intermediate-consequence rule, but one or two in each sample did under the stiffest rule. In one sample there was a quite high (58.3 percent) acceptance rate for the mid-level $\$ 13,000$ offer under the maximum-consequence rule.

As for the second hypothesis, concerning the tendency to make counterdemands or hold out, and the amounts counter-demanded, this simulation did not involve a two-way offer rule that plaintiffs could use with respect to

46. Ser generally supra text accompanying notes 13-16, 35-36. 
their own settlement demands. Consequently, no variance by rule type is predicted. Some variations in the counter-demand percentages do appear (for example, combining both samples, 67.7 percent under the minimumconsequence rule and 72.8 percent under the other two together), but they are not statistically significant. The inclination to make counter-demands is fairly high-50 percent or above in every possible scenario in both populations-but fluctuates almost randomly with rule type and offer level.

Mean counter-demands, however, were notably lower $(\$ 43,230)$ when plaintiffs were threatened with possible neutralization or reversal of their section 1988 fee entitlement than they were under the rule interpretation leaving that entitlement unaffected. The mean counter-demand under that rule was $\$ 51,872$, and the difference was significant at the .05 level. ${ }^{47} \mathrm{High}$ outlier counter-demands (defined for this simulation as at least $\$ 75,000$, the level at which subjects were told a jury "just might" return a verdict) were also less frequent under the neutralizing or reversing Rule 68 interpretations11.1 percent versus 23.3 percent under the no-change approach; the significance level again was less than .05 . Offer rules may thus moderate plaintiffs' counter-demands whether the rules are available to both sides or to defendants only. From our limited data, however, we see signs of a significant "smoke out" effect on early plaintiffs' offers only in the tort simulation under the rule available to plaintiffs as well as to defendants. ${ }^{48}$ This effect is consistent with our original hypothesis. ${ }^{49}$

\section{IV}

\section{Conclusions}

\section{A. Policy Implications}

At this preliminary stage, we must approach circumspectly even a brief discussion of potential policy implications of our work. Much more extensive, complex, and realistic research remains to be done before we can speak with some confidence of empirical knowledge about the effects of offer devices. Of course, value judgments must also play a role in decisions concerning whether

47. For one possible explanation of this demand-moderation effect even without the benefit of triggering a rule addressed to plaintilfs fee entitlement, see supra note 4l: In our civil rights simulations, defendants had made offers that adversely affected plaintiffs expected net gain from trial, which will tend to reduce counter-demands. In more general terms, plaintiffs who reject oflers but face fee consequences-even when their own offers have no formal effect on fee liability-are likely to feel greater pressure to scule and thus to make lower counter-demands.

48. Sep supra text following note 45.

49. At the end of our introductory discussion of hypotheses for testing, see supra text following note 41, we mentioned possible effects for which it seemed hard to formulate hypotheses in advance. The only one that we have not yet discussed in our presentation of results concerns the impact of initial offer levels on amounts of counter-demands. Plaintiffs might, for example, either demand more in response to a low offer in an effort to maintain room to bargain, or on the contrary demand less in an attempt to keep settement chances alive and perhaps because the initial offer affected their sense of what their own case was worth. In aggregate data mean counter-demands tended to rise slightly with higher offers. but the many irregular variations among scenarios within individual groups suggest the need for larger samples-and especially for research involving practitioners, rather than students, before any conclusions would be wartanted. 
to change existing offer rules. Subject to these severe limitations, it may still remain possible to suggest some policy applications that our early findings could have if confirmed by further research. With respect to the relative acceptance rate under regimes with and without offer rules affecting liability for post-offer fees: Small or non-existent differential impacts (like those in our tort simulation) suggest that choices between different possible regimes should rest primarily on a sense of equity rather than on hypothesized incentive effects. It is easy to overdo an ex post sense of fairness and not to pay enough attention to ex ante incentive effects;50 but if incentive effects are small or absent, then ex post considerations have the field more or less to themselves.

The two simulations used in this study provide good illustrations of possible lesser and greater impact differences, and thus of the conceivably different terms in which policy questions in this field might be approached. There appeared to be no significant differences in effect between benefit-ofthe-bargain and full fee shifting rules in the first simulation. The policy implications could go in either direction, depending on values and other research results: Possibly, the "benefit" version is simply too complicated for most litigants and even their lawyers to grasp readily, and therefore should not be adopted. On the other hand, with moderate experience parties and especially attorneys might catch on; if effects still are quite similar under both versions, then the choice should be guided by ex post notions of fairness and how rigorously a litigant should be treated after declining and failing to improve upon a formal settlement offer. But when the impact seems quite marked-as with the different civil rights offer regimes studied so far in our limited research-that result might join with equity concerns to suggest that the maximum-consequence rule is unnecessary to achieve significant incentive effects. Such a strong impact could even, depending on its magnitude, raise questions about the consistency of the measure with congressional intent in passing the fee shifting statutes.

Often our research results show the need for further work more than they support any present policy implications. Such appears to be the case with the modest confirmation of the increased-acceptance, "smoke-out", and demandmoderation hypotheses in our preliminary data. These effects, even if confirmed with needed additional work directed at the same hypotheses, are only part of the picture. They could mean more and earlier settlements, which would be widely although perhaps not universally regarded as a benefit. But even putting aside issues about the general desirability of settlement, ${ }^{51}$ the possible "dig-in" effect requires broader and more complex research to see if it is possible to reach any conclusions about net impact on settlement rates.

50. Sep generally Easterbrook, The Supreme Court, 1983 Term-Foreword: The Cout and the Economic System, 98 HARV. I. REv. 4 (1984).

51. Sep supra text accompanying notes 5-7. 


\section{B. Further Research and Advanced Hypotheses}

The simulation research reported here is a valuable first step and might profitably be repeated, especially on populations with more real-world experience such as litigating lawyers. But several additional steps remain before the indications from the present work can be treated as anything more than highly tentative. Further studies can profitably use two-sided interactive simulations, rather than one-sided questionnaires; interactive situations could be between two persons or two lawyer-client teams, or perhaps could involve a computer on one side for regularity. In either case, specifically drafted rules rather than the general descriptions used thus far would be essential-and would be valuable to perfect drafting for real-world applications as well as to inject verisimilitude. And, of course, an ideal experiment would involve rule variation on a significant flow of similar actual cases, which might come from cases voluntarily referred to Duke's Private Adjudication Center or to another alternative dispute resolution program.

Such advanced research would make it possible to test more complex hypotheses, including even some fairly fundamental ones about litigant behavior beyond specific issues concerning offer of settlement rules. On the impact of offer rules, many more questions would lend themselves to testing, such as the timing of settlements and the amounts at which parties settle. An issue beyond the impact of offer rules is whether-effects on settlement rates aside-fee shifting would raise or lower the level of expenditure on litigation. ". Lawyer time spent under different offer rules might be a good proxy measure.

Recent theoretical literature has also contained discussion of the relative roles of "optimism" and "strategic behavior" models of litigant behavior.5.3 Briefly, the optimism model hypothesizes that litigant decisions whether to settle or go to trial depend primarily upon expectations of the net result of trial versus the settlement terms available. The strategic behavior model proposes that in seeking to maximize gains, parties may take chances on hard bargaining that will sometimes take them to trial even when the optimism model would predict settlement. ${ }^{5-4}$ Without going into great detail here, suffice it to say that different fee and perhaps offer regimes might permit testing to determine which model more fully accounted for observed behavior.5.5 If we can achieve a fraction of this research agenda, we can consider ourselves fortunate.

52. Sep Katz, Measuring the Demand for Litigation: Is the English Rule Really Cheaper?. 3 J. L. Econ. \& OrG. 143 (1987).

53. Compare Trubek, Sarat, Felstiner, Kritzer \& Grossman, The Costs of Ordinary Litigation, 31 UCI.A I. REv. 72, 104 (1983) (discussing oprimism and strategic behavior models). ailh Cooter. Marks \& Mnookin, supua note 18, at 246 (proposing empirical test of strategic behavior model in different fec shifting situations).

54. For a concise discussion of how strategic bargaining can lead to trial rather than settement, sce R. CoOtri \& T. Ulen, I aW and EConomics 487.92 (1988).

55. Sep Cooler, Marks \& Mnookin, supra note 18. 


\section{Tabular Appendix}

Explanation of Tables. The following tables present the statistical results from our simulations: Tables 1 through 4 from the tort scenario described in the body of the article, and Tables 5 through 7 from the civil rights simulation. Tables 4 and 7 give aggregate data for groups doing the same simulation, and the others present results by individual groups. The first line on rule type states the kind of offer of settlement rule applicable in the various scenarios, using shorthand references to the descriptions in the text-in Tables 1 through 4 , these references include situations using no offer rule, the benefit-of-the-bargain version, and the full-liability approach.* In Tables 5 through 7, the rule headings refer to interpretations of Federal Rule of Civil Procedure 68 that would leave a federal civil rights plaintiff's section 1988 fee entitlement unaffected, neutralized, or reversed, respectively.** With the offer amounts in the left-hand column, the tables thus present three-by-three matrices for the various effects in each of the nine possible combinations of rule type and offer amount, with totals at the side and bottom.

The rows under each offer amount, after giving the total number ("N") of responses under each rule type, first give the percentage of subjects who said they would be inclined to accept or would advise accepting the defendant's offer now. The next pair of rows gives the number of subjects rejecting the offer and the percentage of those subjects who would be inclined to make or who would advise making a counter-demand now. The final row under each offer amount gives the mean amount counter-demanded under the various rules.

The lines under the total figures at the bottom of each table first give the percent of subjects accepting under each rule type. The remaining lines give in turn the number rejecting initial offers and the percentage of those subjects who would make immediate counter-demands, the mean amounts counterdemanded, and the percentage of counter-demands regarded as high outliers (at least $\$ 60,000$ in the tort simulation and $\$ 75,000$ in the civil rights simulation).

The footnotes to each table give statistical significance for some of the relationships presented in the table. The " $p$ " is the conventional symbol for reporting probability levels. The " $>$ " and " $<$ " symbols signify whether a probability level is greater or less than the figure that follows; again, the higher the figure, the more likely the results are due to chance-i.e., lower figures mean greater statistical significance. In most cases, the comparisions are of differences between the minimum-consequence offer rule on the one hand and the medium-and maximum-consequence rules taken together on the other, thus permitting contrast between the effects observed under offer rules with some impact on fee entitlement or liability versus rules with no such impact.

* Spe supra text accompanying notes 33-34.

** Sef supra text accompanying note 36 . 


\section{TABLE 1}

\section{Group 1: Tort, Duke University upperclass laW}

Offer rule type

Offer amount

$\$ 30,000 \mathrm{~N}$

Acceptance rate

No. rejecting

Counter-demand rate

Mean counter-demand"

$\$ 35,000 \quad \mathrm{~N}$

Acceptance rate

No. rejecting

Counter-demand rate

Mean counter-demand"

$\$ 40,000 \mathrm{~N}$

Acceptance ratc

No. rejecting

Counter-demand rate

Mean counter-demand

Total N

Acceptance rate

No. rejecting

Counter-demand rate"

Mean counter-demand ${ }^{t}$

$\%$ high outliers"
Nòne

"Benefit"

Full

Total

$\begin{array}{rccc}14 & 12 & 11 & 37 \\ 7.1 \% & 16.7 \% & 27.3 \% & 16.2 \% \\ 13 & 10 & 8 & 31 \\ 92.3 \% & 100.0 \% & 100.0 \% & 96.8 \% \\ \$ 50.936 & \$ 46.000 & \$ 49,688 & \$ 49.022\end{array}$

10

$10.0 \%$

9

$77.8 \%$

$\$ 54,286$

13

$53.9 \%$

6

$83.3 \%$

$\$ 55,500$

37

$24.3 \%$

28

$85.7 \%$

$\$ 52.787$

$20.8 \%$
12

$41.7 \%$

7

$100.0 \%$

$\$ 54,286$

13

$69.2 \%$

4

$100.0 \%$

$\$ 46.875$

37

$43.2 \%$

21

$100.0 \%$

$\$ 48.929$

$9.5 \%$
15

$20.0 \%$

12

$100.0 \%$

$\$ 45,042$

11

$54.6 \%$

5

$100.0 \%$

$\$ 51,000$

37

$32.4 \%$

25

$100.0 \%$

$\$ 47,720$

$8.0 \%$
37

$24.3 \%$

28

$92.9 \%$

$\$ 50.019$

37

$59.5 \%$

15

$93.3 \%$

$\$ 51,429$

111

$33.3 \%$

74

$94.6 \%$

$\$ 49.862$

$12.9 \%$

"Comparison of difference between "None" and combined "Benefit"-"Full", $p>.25$.

" Comparison of difference belween "None" and combined "Benefit"-"Full", $p>10$

" Comparison of diflerence between "None" and combined "Benefit"-"Full", $p<.10$.

"Comparison of difference among "None," "Bencfit." and "Full", $p>.20$; between "None" and combined "Benefit"."Full," $p>.15$.

"Comparison of difference between "None" and combined "Benefie"."Full". $p<.01$ (but sample size small).

1 Comparison of difference between "None" and combined "Benefit"-" $\mathrm{Full} ", p<.05$.

"Comparison of difference between "Nonc" and combined "Benefit" " Full" $p=.15$ (and sample size small). 
TABLE 2

Group 2: Tort, Washington University UPPERClass LaW

Offer rule type

Offer amount

\begin{tabular}{|c|c|}
\hline$\$ 30,000$ & $\begin{array}{l}\mathrm{N} \\
\text { Acceptance rate } \\
\text { No. rejecting } \\
\text { Counter-demand rate } \\
\text { Mcan counter-demand" }\end{array}$ \\
\hline$\$ 35,000$ & $\begin{array}{l}\text { N } \\
\text { Acceptance rate } \\
\text { No. rejecting } \\
\text { Counter-demand rate } \\
\text { Mean counter-demand" }\end{array}$ \\
\hline$\$ 40,000$ & $\begin{array}{l}\text { N } \\
\text { Acceptance rate } \\
\text { No. rejecting } \\
\text { Counter-demand rate } \\
\text { Mean counter-demand }\end{array}$ \\
\hline Total & $\begin{array}{l}\text { N } \\
\text { Acceptance rate } \\
\text { No. rejecting } \\
\text { Counter-demand rate } \\
\text { Mean counter-demand } \\
\text { \% high outliers }\end{array}$ \\
\hline
\end{tabular}

None

"Benefit"

Full

Total

22
$9.1 \%$
20
$90.0 \%$
$\$ 58,056$

20

$40.0 \%$

12

$83.3 \%$

$\$ 58,000$

22

$50.0 \%$

11

$81.8 \%$

$\$ 64,389$

64

$32.8 \%$

43

$86.1 \%$

$\$ 59,581$

$54.1 \%$

21
$0.0 \%$
21
$100.0 \%$
$\$ 49.810$
23
$43.5 \%$
13
$76.9 \%$
$\$ 46.250$

20

$50.0 \%$

10

$80.0 \%$

$\$ 52,500$

64

$31.3 \%$

44

$88.6 \%$

$\$ 49,449$

$15.4 \%$
21

$33.3 \%$

14

$85.7 \%$

$\$ 45,417$

21

$19.1 \%$

17

$76.5 \%$

$\$ 52,536$

22

$68.2 \%$

7

$85.7 \%$

$\$ 47,500$

64

$40.6 \%$

38

$81.6 \%$

$\$ 48,922$

$6.5 \%$
64

$14.1 \%$

55

$92.7 \%$

$\$ 51,686$

64

$34.4 \%$

42

$78.6 \%$

$\$ 52,294$

64

$56.3 \%$

28

$82.1 \%$

$\$ 55,848$

192

$34.9 \%$

125

$85.6 \%$

$\$ 52,764$

$26.2 \%$

" Comparison of difference between "None" and combined "Benefie"."Full". $p<.05$.

" Comparison of difference between "None" and combined "Benefit"." Full", $p<.05$.

"Comparison of difference between "Nonc" and combined "Benefie"."Full", $p<.01$.

"Comparison of difference among "None," "Benefit," and "Full". $p>45$; between "None" and combined "Benefit"-"Full," $\rho>.60$.

"Comparison of difference between "None" and combined "Benefit"."Full", $p>90$.

1 Comparison of difference between "None" and combined "Benefit"." Full". $p<.01$.

"Comparison of difference between "None" and combined "Benefit"."Full". $p<.01$. 
TABLE 3

\section{Group 3: Tort, Duke University graduate business}

Offer rule type

Offer amount

\begin{tabular}{|c|c|}
\hline$\$ 30,000$ & $\begin{array}{l}\text { N } \\
\text { Acceptance rate } \\
\text { No. rejecting } \\
\text { Counter-demand rate } \\
\text { Mean counter-demand }\end{array}$ \\
\hline$\$ 35,000$ & $\begin{array}{l}\text { N } \\
\text { Acceptance rate } \\
\text { No. rejecting } \\
\text { Counter-demand rate } \\
\text { Mean counter-demand' }\end{array}$ \\
\hline$\$ 40.000$ & $\begin{array}{l}\text { N } \\
\text { Acceptance rate } \\
\text { No. rejecting } \\
\text { Counter-demand rate } \\
\text { Mean counter-demand }\end{array}$ \\
\hline Total & $\begin{array}{l}\text { N } \\
\text { Acceptance rate } \\
\text { No. rejecting } \\
\text { Counter-demand rate } \\
\text { Mean counter-demand } \\
\text { \% high outliers" }\end{array}$ \\
\hline
\end{tabular}

None

"Benefit"

Full

Total

14
$14.3 \%$
12
$83.3 \%$
$\$ 52.955$

10

$40.0 \%$

6

$83.3 \%$

$\$ 60.000$

14

$57.1 \%$

6

$83.3 \%$

$\$ 54.000$

38

$36.8 \%$

24

$83.3 \%$

$\$ 54,881$

$40.0 \%$

11
$18.2 \%$
9
$100.0 \%$
$\$ 45.778$
15
$53.3 \%$
7
$100.0 \%$
$\$ 46,429$
12
$75.0 \%$
3
$100.0 \%$
$\$ 55,833$
38
$50.0 \%$
19
$100.0 \%$
$\$ 47,605$
$10.5 \%$

13

$30.8 \%$

9

$88.9 \%$

$\$ 46,250$

13

$69.2 \%$

4

$100.0 \%$

$\$ 46,875$

12

$50.0 \%$

6

$100.0 \%$

$\$ 50,333$

38

$50.0 \%$

19

$94.7 \%$

$\$ 47,750$

$5.6 \%$
38

$21.1 \%$

30

$90.0 \%$

$\$ 48,732$

38

$55.3 \%$

17

$94.1 \%$

$\$ 50.781$

38

$60.5 \%$

15

$93.3 \%$

$\$ 52,821$

114

$45.6 \%$

62

$91.9 \%$

$\$ 50,284$

$19.3 \%$

"Comparison of difference between "None" and combined "Benefil"."Full". $p<.10$.

"Comparison of difference between "None" and combined "Benefit"-"Full", $p<.01$.

" Comparison of difference between "None" and combined "Benefit"."Full", $p>.50$.

"Comparison of difference among "Nonc." "Bencfit." and "Full", $p>40$; between "None" and combined "Benefit" "Full," $p>15$.

"Comparison of difference between "None" and combined "Benefit"-"Full". $p<.05$ (but sample size small).

1 Comparison of difference between "None" and combined "Benefit"-"Full", $p<.01$.

"Comparison of difference between "None" and combined "Benefit"-"Full". $f<.01$ (but sample size small). 


\section{TABLE 4}

\section{Groups 1, 2, 3 COMBined: TORT, TOtals}

Offer rule type

Offer amount

\begin{tabular}{|c|c|}
\hline 0,000 & $\begin{array}{l}\text { N } \\
\text { Acceptance rate } \\
\text { No. rejecting } \\
\text { Counter-demand rate } \\
\text { Mean counter-demand }\end{array}$ \\
\hline$\$ 35,000$ & $\begin{array}{l}\text { N } \\
\text { Acceptance rate } \\
\text { No. rejecting } \\
\text { Counter-demand rate } \\
\text { Mean counter-demand" }\end{array}$ \\
\hline$\$ 40,000$ & $\begin{array}{l}\text { N } \\
\text { Acceptance rate } \\
\text { No. rejecting } \\
\text { Counter-demand rate } \\
\text { Mean counter-demand }\end{array}$ \\
\hline Total & $\begin{array}{l}\text { N } \\
\text { Acceptance rate } \\
\text { No. rejecting } \\
\text { Counter-demand rate } \\
\text { Mean counter-demand } \\
\text { \% high outliers }\end{array}$ \\
\hline
\end{tabular}

None

"Benefit"

Full

Tolal

$\begin{array}{lccc}50 & 44 & 45 & 139 \\ 10.0 \% & 9.1 \% & 31.1 \% & 16.6 \% \\ 45 & 40 & 31 & 116 \\ 88.9 \% & 100.0 \% & 90.3 \% & 93.1 \% \\ \$ 54.516 & \$ 47,950 & \$ 46.875 & \$ 50.183 \\ 40 & 50 & 49 & 139 \\ 32.5 \% & 46.0 \% & 32.7 \% & 37.4 \% \\ 27 & 27 & 33 & 87 \\ 81.5 \% & 88.9 \% & 87.9 \% & 86.2 \% \\ \$ 57.273 & \$ 48,646 & \$ 48,783 & \$ 51.197 \\ 49 & 45 & 45 & 139 \\ 53.1 \% & 62.2 \% & 60.0 \% & 58.3 \% \\ 23 & 17 & 18 & 58 \\ 82.6 \% & 88.2 \% & 94.4 \% & 87.9 \% \\ \$ 59.316 & \$ 51,667 & \$ 49,529 & \$ 53,803 \\ 139 & 139 & 139 & 417 \\ 31.7 \% & 39.6 \% & 41.0 \% & 37.4 \% \\ 95 & 84 & 82 & 261 \\ 85.3 \% & 94.1 \% & 90.2 \% & 89.7 \% \\ \$ 56.345 & \$ 48,867 & \$ 48,240 & \$ 51,288 \\ 40.7 \% & 12.7 \% & 6.8 \% & 20.5 \%\end{array}$

"Comparison of difference between "None" and combined "Benefie"-"Full", $p<.(01$.

"Comparison of difterence between "Nonc" and combined "Benefit"."Full", $p<.01$.

" Comparison of difference between "None" and combined "Benefit"."Full", $p<.0 \mathrm{l}$.

"Comparison of difference among "None," "Benefit." and "Full", $>$.25; between "None" and combined "Benefit"."Full," $p<.10$.

"Comparison of difference between "None" and combined "Benefit"-"Full", $p<.10$.

" Comparison of difference between "None" and combined "Bencfit"."Full", $p<.01$.

" Comparison of difference between "None" and combined "Benefit"."Full". $p<.01$. 
TABLE 5

Group 4: Civil rights, Duke University upperclass laW

Fee claim impact

Offer amount

$\begin{array}{ll}\$ 6,000 & \mathrm{~N} \\ & \text { Acceptance rate } \\ & \text { No. rejecting } \\ & \text { Counter-demand rate } \\ & \text { Mean counter-demand } \\ \$ 13,000 & \mathrm{~N} \\ & \text { Acceptance rate } \\ & \text { No. rejecting } \\ & \text { Counter-demand rate } \\ & \text { Mean counter-demand" } \\ \$ 20,000 & \mathrm{~N} \\ & \text { Acceptance rate } \\ & \text { No. rejecting } \\ & \text { Counter-demand rate } \\ & \text { Mean counter-demand } \\ & \text { N } \\ \text { Acceptance rate } & \\ \text { Total } & \text { No. rejecting } \\ & \text { Counter-demand rate } \\ & \text { Mean counter-demand' } \\ & \text { \% high outliers" }\end{array}$

$\begin{array}{cc}\text { None } & \text { Neutralize } \\ & \\ 25 & 21 \\ 0.0 \% & 0.0 \% \\ 25 & 21 \\ 52.0 \% & 61.9 \% \\ \$ 57,304 & \$ 47,905 \\ 26 & 16 \\ 7.7 \% & 25.0 \% \\ 24 & 12 \\ 79.2 \% & 91.7 \% \\ \$ 61,250 & \$ 36.375 \\ 15 & 29 \\ 26.7 \% & 75.9 \% \\ 11 & 7 \\ 100.0 \% & 57.1 \% \\ \$ 44,091 & \$ 53,357 \\ 66 & 66 \\ 9.1 \% & 39.4 \% \\ 60 & 40 \\ 71.7 \% & 70.0 \% \\ \$ 56,259 & \$ 45,400 \\ 33.3 \% & 11.1 \%\end{array}$

Total

66

$\begin{array}{cc}20 & 66 \\ 5.0 \% & 1.5 \% \\ 19 & 65 \\ 63.2 \% & 58.5 \% \\ \$ 37.053 & \$ 48,063\end{array}$

24

$20.8 \%$

19

$89.5 \%$

$\$ 44,105$

22

$77.3 \%$

5

$80.0 \%$

$\$ 47,500$

66

$34.9 \%$

43

$76.7 \%$

$\$ 41,383$

$15.2 \%$
66

$16.7 \%$

55

$85.4 \%$

$\$ 49,472$

66

$65.2 \%$

23

$82.6 \%$

$\$ 47,652$

198

$27.8 \%$

143

$72.7 \%$

$\$ 48.532$

$21.6 \%$

"Comparison of difference between "None" and combined "Neutralize" -"Reverse" $p<.10$.

1. Comparison of difference beeween "None" and combined "Neutralize" "Reverse", $p<.01$.

"Comparison of difference between "None" and combined "Neutralize"." Reverse"., $p>.40$.

"Comparison of difference among "None." "Neutralize," and "Reverse", $p<.01$; between "None" and combined "Neutralize"."Reverse"." $p<.01$.

"Comparison of difference between "None" and combined "Neutralize"-"Reverse". $p>.75$

Comparison of difference between "None" and combined "Neutralize"-"Reverse", $p<.01$.

"Comparison of difletence between "None" and combined "Neutralize"."Reverse". $p<.05$. 
TABLE 6

\section{Group 5: Civil Rights, Washington University first year LaW}

Fee claim impact

Offer amount

\begin{tabular}{|c|c|}
\hline$\$ 6,000$ & $\begin{array}{l}\mathrm{N} \\
\text { Acceptance rate } \\
\text { No. rejecting } \\
\text { Counter-demand rate } \\
\text { Mean counter-demand }\end{array}$ \\
\hline$\$ 13,000$ & $\begin{array}{l}\text { N } \\
\text { Acceptance rate } \\
\text { No. rejecting } \\
\text { Counter-demand rate } \\
\text { Mean counter-demand }\end{array}$ \\
\hline$\$ 20.000$ & $\begin{array}{l}\text { N } \\
\text { Acceptance rate } \\
\text { No. rejecting } \\
\text { Counter-demand rate } \\
\text { Mean counter-demand }\end{array}$ \\
\hline Total & $\begin{array}{l}\text { N } \\
\text { Acceptance rate" } \\
\text { No. rejecting } \\
\text { Counter-demand rate } \\
\text { Mean counter-demand' } \\
\text { \% high outliers }\end{array}$ \\
\hline
\end{tabular}

None

12

$0.0 \%$
12
$50.0 \%$
$\$ 39,625$

11

$0.0 \%$

11

$72.7 \%$

$\$ 40.682$

12

$41.7 \%$

$57.1 \%$

$\$ 55,357$

35

$14.3 \%$

30

$60.0 \%$

$\$ 43,683$

$0.0 \%$
Neutralize

Reverse

Total

11

$0.0 \%$

11

$72.7 \%$

$\$ 37,273$

12

$8.3 \%$

11

$81.8 \%$

$\$ 43,636$

12

$58.3 \%$

5

$60.0 \%$

$\$ 49.500$

35

$22.9 \%$

27

$74.1 \%$

$\$ 42.130$

$10.0 \%$
12

$16.7 \%$

10

$70.0 \%$

$\$ 44,833$

12

$58.3 \%$

5

$60.0 \%$

$\$ 44,800$

11

$100.0 \%$

0

$-$

35

$57.1 \%$

15

$66.7 \%$

$\$ 44.821$

$0.0 \%$
35

$5.7 \%$

33

$63.6 \%$

$\$ 40,281$

35

$22.9 \%$

27

$74.1 \%$

$\$ 42.648$

35

$65.7 \%$

12

$58.3 \%$

$\$ 52,917$

105

$31.4 \%$

72

$66.7 \%$

$\$ 43.317$

$4.2 \%$

. Comparison of difference between "None" and combined "Neutralize"-"Reverse",$p>.90$.

"Comparison of difference between "None" and combined "Neutralize" " Reverse" $p>.70$

" Comparison of difference between "None" and combined "Neutralize"-"Reverse". $p>.70$.

"Comparison of difference among "None." "Neutalize," and "Reverse". $p<.01$; between "Nonc" and combined "Neutralize"-"Reverse", $p<.01$.

"Comparison of difference between "None" and combined "Neutralize"-"Reverse", $p>.30$

1 Comparison of difference between "None" and combined "Neutralize" "Reverse" $. p>.90$

"Comparison of difference between "None" and combined "Neutralize"-"Reverse". $p>.25$. 


\section{TABLE 7}

\section{Groups 4 and 5 combined: Civil rights, totals}

Fee claim impact

Offer amount

$\$ 6,000 \quad \mathrm{~N}$

Acceptance rate

No. rejecting

Counter-demand rate

Mean counter-demand"

$\$ 13.000 \mathrm{~N}$

Acceptance rate

No. rejecting

Counter-demand rate

Mean counter-demand"

$\$ 20,000 \quad \mathrm{~N}$

Acceptance rate

No. rejecting

Counter-demand rate

Mean counter-demand'

Total N

Acceplance rate

No. rejecting

Counter-demand rate

Mean counter-demand ${ }^{\prime}$

$\%$ high outliers
None

37

$0.0 \%$

37

$51.4 \%$

$\$ 51,243$

37

$5.4 \%$

35

$77.1 \%$

$\$ 54,394$

27

$33.3 \%$

18

$83.3 \%$

$\$ 48,472$

101

$10.9 \%$

90

$67.7 \%$

$\$ 51.872$

$23.3 \%$
Neutralize

Reverse

32

$9.4 \%$

29

$65.5 \%$

$\$ 39,554$

36

$33.3 \%$

24

$83.3 \%$

$\$ 44,250$

33

$84.9 \%$

5

$80.0 \%$

$\$ 47,500$

$\$ 51,750$

101

$33.7 \%$

67

$71.6 \%$

$\$ 44,082$

$10.6 \%$
101

$42.6 \%$

58

$74.1 \%$

$\$ 42,228$

$11.6 \%$
Total

101

$3.0 \%$

98

$60.2 \%$

$\$ 45,442$

I01

$18.8 \%$

82

$81.7 \%$

$\$ 47.169$

101

$65.3 \%$

35

$74.3 \%$

$\$ 49,457$

303

$29.0 \%$

215

$70.7 \%$

$\$ 46,769$

$16.0 \%$

"Comparison of diflerence between "None" and combined "Neutralize"-"Reverse". $p<.15$.

1. Comparison of difference between "None" and combined "Neutralize" " Reverse" $p<.05$.

"Comparison of dillerence between "None" and combined "Neutralize"-"Reverse", $p>75$.

"Comparison of diflerence among "None," "Neumalize," and "Reverse", $p<.01$; betueen "None" and combined "Neutralize"-"Reverse"," $p<.01$.

"Comparison of difference between "None" and combined "Neutralize"-"Reverse". $p>40$.

t Comparison of difference between "None" and combined "Neutralize" " Reverse" $p<.05$.

" Comparison of difference between "None" and combined "Neutralize" "Reverse" $p<.05$. 
